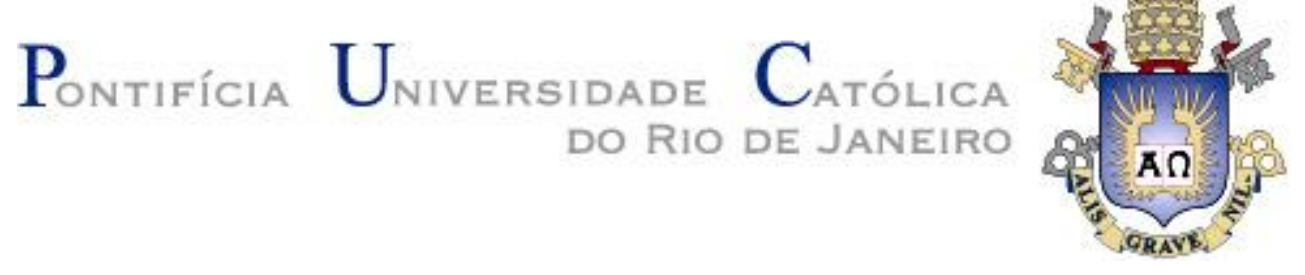

Fernanda Imperial da Silva Pereira

\begin{abstract}
Interpretações das princesas Disney por mulheres de duas gerações: crenças, valores e comportamentos
\end{abstract}

Dissertação de Mestrado

Dissertação apresentada ao Programa de PósGraduação em Administração de Empresas da PUC-Rio como requisito parcial para obtenção do grau de Mestre em Administração de Empresas.

Orientador: Prof. Luis Fernando Hor-Meyll Co-orientador: Prof. Paulo De Lancreste

Rio de Janeiro

Outubro de 2019 


\section{Interpretações das princesas Disney por mulheres de duas gerações: crenças, valores e comportamentos}

Dissertação apresentada como requisito parcial para obtenção do grau de Mestre pelo Programa de PósGraduação em Administração de Empresas da PUC-Rio. Aprovada pela Comissão Examinadora abaixo.

Prof. Luis Fernando Hor-Meyll Alvares Orientador

Departamento de Administração - PUC-Rio

Prof. Paulo de Neville da Cunha Sepulveda e Lencastre

Co-Orientador Universidade Católica Portuguesa -Porto- UCP

Prof. Luis Alexandre Grubits de Paula Pessôa

Departamento de Administração - PUC-Rio

Prof ${ }^{a}$. Denise Franca Barros Universidade do Grande Rio - UNIGRANRIO

Rio de Janeiro, 11 de Outubro de 2019 
Todos os direitos reservados. É proibida a reprodução total ou parcial do trabalho sem autorização da universidade, do autor e do orientador.

Fernanda Imperial da Silva Pereira

Graduada em Comunicação Social-Publicidade pela Pontifícia Universidade Católica do Rio de Janeiro.

Ficha Catalográfica

\section{Pereira, Fernanda Imperial da Silva}

Interpretações das princesas Disney por mulheres de duas gerações : crenças, valores e comportamentos / Fernanda Imperial da Silva Pereira ; orientador: Luis Fernando Hor-Meyll ; coorientador: Paulo de Lancreste. - 2019.

49 f. ; $30 \mathrm{~cm}$

Dissertação (mestrado)-Pontifícia Universidade Católica do Rio de Janeiro, Departamento de Administração, 2019.

Inclui bibliografia

1. Administração - Teses. 2. Gerações. 3. Baby boomers. 4. Millennials. 5. Papéis sociais femininos. 6. Contos de fadas Disney. I. Hor-Meyll, Luis Fernando. II. Lancreste, Paulo de. III. Pontifícia Universidade Católica do Rio de Janeiro. Departamento de Administração. IV. Título. 
Para os meus pais, Lilian e Fernando. 


\section{Agradecimentos}

Ao meu orientador Professor Luis Fernando Hor-Meyll e meu co-orientador Professor Paulo De Lancreste pela motivação e parceria para a realização deste trabalho.

À PUC-Rio e ao CNPQ, pelo auxílio concedido, sem o qual este trabalho não poderia ter sido realizado.

Aos meus pais, Lilian e Fernando, por todo apoio, educação, confiança e carinho.

Ao meu marido Rafael Da Conceição Pereira, pelo companheirismo e suporte em toda a minha jornada acadêmica.

Aos professores que participaram da Comissão examinadora.

A todos os professores e funcionários do Departamento pelos ensinamentos e ajuda.

A todos os amigos e familiares que me estimularam e ajudaram nessa caminhada. Em especial minha tia Ilda Lopes e meus amigos, Érica Teixeira, Vinícius Duarte, Tatiana Damianni e Paula Sirimarco, por todo apoio e ajuda ao longo do mestrado. 


\section{Resumo}

Pereira, Fernanda Imperial da Silva; Alvares, Luis Fernando Hor-Meyll. Interpretações das princesas Disney por mulheres de duas gerações: crenças, valores e comportamentos. Rio de Janeiro, 2019. 49p. Dissertação de Mestrado - Departamento de Administração, Pontifícia Universidade Católica do Rio de Janeiro.

Este estudo buscou identificar como mulheres de baixa renda, das gerações Baby Boomers e Millennials, interpretam e reagem à mudança do papel feminino nos contos de Disney e a sua influência na percepção da marca. Foram conduzidas dezesseis entrevistas em profundidade com mulheres, moradoras do Estado do Rio de Janeiro. A partir de lembranças e experiências vividas das entrevistadas em relação a marca e aos filmes, e empregando também dois filmes previamente selecionados que marcaram as duas gerações, Cinderela (1950) e Frozen (2014), foram obtidos resultados que apresentaram evidências de diferentes reações e identificações, provocadas pelas princesas nos filmes, denotando papéis sociais femininos dentro da sociedade. A geração a que pertencem e o nível socioeconômico das entrevistadas parece influenciar em suas reações.

\section{Palavras-chave}

Gerações; Baby Boomers; Millennials; Papéis sociais femininos; Contos de fadas Disney. 


\section{Abstract}

Pereira, Fernanda Imperial da Silva; Alvares, Luis Fernando Hor-Meyll (Advisor). Interpretations of Disney princesses by women of two generations: beliefs, values and behaviors. Rio de Janeiro, 2019. 49p. Dissertação de Mestrado - Departamento de Administração, Pontifícia Universidade Católica do Rio de Janeiro.

This study aimed to identify how low-income women, representatives of the Baby Boomers and Millennials generations interpret and react to the changing role of women in Disney tales and their influence on brand perception. Sixteen indepth interviews were conducted with women from Rio de Janeiro State. From the memories and lived experiences of the interviewees regarding the brand and the films, and also employing two previously selected films that marked the two generations, Cinderela (1950) and Frozen (2014), results were obtained that showed evidence of different reactions and identifications provoked by the princesses in the movies, denoting female social roles within society. The generation to which they belong and the socioeconomic level of the interviewees seem to influence their reactions.

\section{Keywords}

Generations; Baby Boomers; Millennials; Female Social Roles; Disney fairy tale. 


\section{Sumário}

1. Introdução 10

$\begin{array}{ll}1.1 \text { Objetivo } & 12\end{array}$

1.2 Relevância 12

$\begin{array}{ll}1.3 \text { Delimitação } & 13\end{array}$

2. Revisão de literatura 14

2.1 Papéis na cultura e na família 14

2.2 Gerações Baby Boomers e Millennials 16

$\begin{array}{ll}2.3 \text { Arquétipos geracionais } & 18\end{array}$

2.4 Papel feminino dentro das gerações 20

2.5 Marca e personagens a ela associadas 21

$\begin{array}{ll}2.6 \text { Princesas Disney } & 23\end{array}$

3. Método 26

$\begin{array}{lr}3.1 \text { Cinderela } & 27\end{array}$

$\begin{array}{ll}3.2 \text { Frozen } & 28\end{array}$

$\begin{array}{ll}3.3 \text { Condução da entrevista } & 29\end{array}$

4. Explicitação dos dados 30

$\begin{array}{ll}\text { 4.1 Perfil das entrevistadas } & 30\end{array}$

4.2 Família 33

$\begin{array}{ll}\text { 4.3 Marca } & 36\end{array}$

$\begin{array}{ll}\text { 4.4 Personagens } & 39\end{array}$ 
5. Considerações Finais

6. Referências Bibliográficas

\section{Lista de tabela}

Tabela 1 - Coortes Baby Boomers

\section{Lista de quadro}

Quadro 1 - Perfil das entrevistadas 


\section{Introdução}

Era uma vez uma princesa muito bela, gentil, amiga dos animais, que estava à procura do príncipe encantado para lhe salvar. O conto clássico de princesas remete a um estereótipo de princesa muito utilizado nos contos de fadas. Uma cena presente no novo filme da Disney, "WiFi Ralph: Quebrando a internet" (2019), mostra as princesas conversando de forma bem descontraída e comentando sobre essas características. Na cena, Penélope, a heroína do videogame, aparece dizendo que também é uma princesa. E elas perguntam: "Você tem cabelo mágico? Mãos mágicas? Foi sequestrada ou escravizada? Todo mundo acha que tudo se resolveu depois que apareceu um homem fortão?" (FANTÁSTICO, 2018).

A ousadia da cena mostra que as qualidades das princesas foram gradualmente sendo modificadas. Dias e Cassiano (2010) apontam que a mulher ocupava posição de submissão, pois tinha como representação uma figura frágil, indefesa, dependente e do lar, como nos desenhos da Cinderela, Branca de Neve e Bela Adormecida. Com o passar das décadas, a partir dos anos 1960, observa-se, na figura das princesas dos filmes da Disney ${ }^{1}$ a alteração do papel feminino.

Atualmente, The Walt Disney Company, (Disney, como será usado nesta dissertação) está investindo em live-actions - animações que ganham versão real com atores reais -, de seus filmes renomados,. Algumas reproduções de princesas já ganharam a sua versão, como Malévola (2014), Cinderela (2015), A Bela e a Fera (2017) e Aladdin (2019). Outros, como Mulan, têm estreia prevista para 2020. Entretanto, para estar de acordo com a realidade social atual, algumas modificações estão sendo feitas - novas personagens estão sendo criadas e outras sendo descartadas. Em Mulan, a história sofrerá modificações para ficar mais parecida com a lenda chinesa, para não decepcionar os fãs que não gostaram da forma como o dragão, animal sagrado da cultura chinesa foi representado no primeiro filme (O FUXICO, 2019). A empresa está investindo em live-actions para atrair o público adulto que assistia os desenhos quando

${ }^{1}$ Branca de Neve e os sete anões (1938), Cinderela (1950), A Bela Adormecida (1959), A Pequena Sereia (1989), Aladdin (1994), A Bela e a Fera (1994), Pocahontas (1995), Mulan (1998), A Princesa e o Sapo (2009), Enrolados (2011), Valente (2012), Frozen: uma aventura congelante (2014), Moana- uma mar de aventuras (2017) e WiFi Ralph: Quebrando a internet (2019). 
mais jovem, buscando criar sentimento de nostalgia e também levar novas pessoas para conhecer os filmes, como os seus filhos.

A marca - definida pela American Marketing Association (AMA, 1960) como um nome, termo, sinal, símbolo ou desenho, ou uma combinação desses elementos, que pretende identificar os bens de um vendedor ou grupo de vendedores e diferenciá-los daqueles dos concorrentes - mostra-se preocupada em acompanhar a evolução com a escolha audaciosa de alguns personagens, como no caso do live-action da Pequena Sereia que não tem data para a estreia, mas já está causando alvoroço nas redes sociais pela escalação de uma atriz negra para dar vida à princesa Ariel. A escolha modifica a personagem, que na versão original é branca e ruiva.

Para Sara Kislanov, supervisora de psicoterapia infantil da PUC-Rio:

"As novas princesas têm força porque falam com o mundo atual. Os pontos positivos das outras histórias permaneceram nas novas narrativas e o que foi ruim está sendo contestado. Acho que é por isso que, de uma maneira geral, as princesas continuam tendo espaço na sociedade" (O GLOBO ONLINE, 2019).

As marcas lidam com temáticas sociais ao se relacionarem com indivíduos e, paralelamente, promovem um discurso identitário, que dá sentido ao mundo. Transformações sociais mudaram valores culturais, o que acarretou alterações nas personagens para se enquadrarem ao novo papel da mulher. A Disney deles se apodera para transformá-los em proposta de valor.

As novas produções de Disney reviram seus posicionamentos para estarem ajustadas com valores e papéis dos consumidores na nova conjuntura. Karla Holanda, professora da UFF, considera que a mudança tem como motivação o lucro e não o comprometimento ideológico com o papel social da mulher: "O capitalismo tem acesso à contemporaneidade e isso significa lucro. $A$ sociedade é plural e está gritando! A indústria tem preocupação em acompanhar isso. Os estúdios Disney estão atentos, eles não querem ficar para trás (O GLOBO ONLINE, 2019).

Este estudo, com característica intergeracional, permitiu comparar o mesmo fenômeno, a influência do papel feminino na interpretação da marca Disney, entre representantes de duas gerações, identificando valores, comportamentos e representações sociais. 
Escolheu-se participantes femininos de baixa renda. Optou-se por considerar como critério para classificar baixa renda o rendimento mensal entre um e três salários mínimos (GROSSI; MOTTA; HOR-MEYLL, 2008). A escolha por mulheres de baixa renda deve-se a estudos que apontam comportamentos mais conservadores (HEILBORN, 1995; ROCHA-COUTINHO, 2006; PARENTE, 2008), laços familiares fortes com um papel designado para cada membro da família (CASTILHOS; ROSSI, 2009) e a possível mudança na relação entre família e gênero nas camadas populares (DUARTE, 2008).

\subsection{Objetivo}

Identificar como o papel de personagens femininas da Disney é interpretado, a partir de valores, crenças e comportamentos, por mulheres de baixa renda das gerações Baby Boomers (nascidos entre 1946-1964) e Millennials (pessoas que estavam no seu período formativo, o fim da adolescência e entrada na fase adulta, durante a virada do milênio).

\subsection{Relevância}

Há um número considerável de estudos (Figueira,1981, 1987, 1991, Magalhães,1993; Nolasco,1993, 1995; Heilborn, 1995; Araújo; Scalon, 2005; Rocha-Coutinho, 2006; e Duarte, 2008), que estudaram temas como visão de mundo, valores, representações sociais e família, que evidenciam a convivência do modelo tradicional, onde o papel da mulher apenas pertencendo ao âmbito familiar e privado, com o modelo moderno, mais igualitário na relação entre homens e mulheres.

No entanto, não foram encontrados estudos, entre gerações diferentes, que utilizem a identificação com personagens femininas de filmes infantis e sua identificação com novas características e com a adequação a papéis femininos da sociedade moderna.

As informações poderão ser de interesse para organizações que buscam entender esses dois segmentos geracionais, pois, ao distinguirem os valores e comportamentos próprios de cada grupo, poderão criar personagens que representem e se adequem a valores e comportamentos dos consumidores. 


\subsection{Delimitação}

O estudo concentra-se na identificação e representação feminina, transmitidas pelas personagens dos filmes de princesa da Disney, vividas pelas entrevistadas representantes de duas gerações distintas de uma mesma classe social, nos impactos gerados na imagem da marca na escolha das novas personagens e na interpretação por ela gerada.

O conceito de gênero e marca não serão abordados profundamente para dar maior ênfase nos impactos gerados à marca dos valores e comportamentos característicos das duas gerações estudadas, Baby Boomers e Millennials. 


\section{Revisão da literatura}

Para dar base ao entendimento das falas das participantes foi importante uma breve aproximação sobre o que é ser mulher para a sociedade e dentro da família. Entender o papel que a mulher exerce em cada um e como esses dois ambientes influenciam e interferem nos valores adquiridos ao longo da vida e consequentemente na percepção da marca, na ótica do estudo proposto.

\subsection{Papéis na cultura e na família}

A teoria dos papéis sociais sexuais desenvolvida por Parsons (1970) define status como sendo o local que o ator social ocupa no sistema social, e papel como o desempenho desenvolvido por esse ator no sistema relacional. Esses sistemas estruturam-se em três aspectos: o ator individual, o sistema social como um todo e o sistema de pautas culturais. As pautas culturais estabelecem padrões e expectativas associadas a cada papel desempenhado. Se um ator não cumpre a expectativa esperada ele sofre uma sanção negativa de desaprovação.

O papel social determina a estrutura social como um conjunto de direitos, deveres e normas que moldam o comportamento humano dentro de um grupo ou organização. Os papéis sociais conferem status, são resultados da socialização e significados atribuídos pela sociedade e envolvem comportamentos e pensamentos que determinam a consciência coletiva. O que difere uma sociedade da outra são os papéis que cada uma atribui a seus participantes desde o momento do nascimento. Todo indivíduo ocupa uma posição e muitos são os papéis que desempenha ao longo da vida (MARTINS, 2010).

A sociedade constitui-se em abundante fonte de estereótipos, que esculpe sistemas valorativos que modelam comportamentos e papéis positivos ou negativos que são aprendidos, transmitidos e modificados por intermédio dos grupos de influência - pais, amigos, professores e meios de comunicação de massa, responsáveis por transmitir estereótipos coletivos a bilhões de pessoas (PEREIRA, 2002). 
Além da influência nos papéis sociais, o sexo (feminino ou masculino) e o contexto familiar a qual pertence a criança interferem na socialização, na localização do indivíduo dentro da sociedade e no papel sexual que exerce (PARSONS, 1970). Ao pensar em gênero, os papéis feminino e masculino são entendidos como não universais, pois são construídos histórica, social e culturalmente. São tipificações do que seria apropriado à mulher e ao homem em determinado contexto, que são aprendidos e transmitidos ao longo de gerações.

A dicotomia sexual homem-mulher tem suas peculiaridades e características definidas culturalmente. Espera-se que meninos sejam "fortes, independentes, agressivos, competentes e dominantes", enquanto as meninas tornem-se "dependentes, sensíveis, afetuosas e que reprimam seus impulsos agressivos e sexuais" (BIAGGIO, 1976 apud Negreiros e Carneiro, 2004, p. 2).

A família é a grande responsável pela manutenção, transmissão e transformação de papéis e representações sociais. A partir dos anos 1970, as transformações sociais, econômicas e culturais ocasionaram grandes mudanças nas relações matrimoniais. A expansão da escolarização e a profissionalização representaram para as mulheres de classe média uma complementação do casamento. Já para as de classe popular, a oportunidade não era a mesma, pois muitas não podiam deixar de lado tarefas domésticas e famílias (VAITSMAN, 1994).

Com a inserção da mulher na esfera pública, as relações familiares e de gênero modificaram-se. A figura masculina passou a participar mais de tarefas domésticas e do cuidado com os filhos, mas ainda exerce papel coadjuvante nesses afazeres. Para Trindade, Andrade e Souza (1997), a mudança do papel do pai na família está relacionada à relação pai-filho, mas não na divisão das tarefas da casa e de responsabilidade a ela relacionadas. Romaneli (1998) corrobora com essa ideia. ao argumentar que o homem tem relutância em aceitar e colaborar com tarefas domésticas, devido ao modelo convencional de família interiorizado. Assim, o que deveria ser uma grande conquista da mulher acaba sobrecarregando o seu papel em uma jornada tripla - provedora, dona de casa e mãe.

A divisão de tarefas ainda está pautada na antiga divisão dos sexos e "a antiga ideia de que "mãe é mãe" e de que "só a mãe sabe como melhor cuidar de seus filhos" continua a prevalecer (ROCHA-COUTINHO, 2003, p. 94).

Ainda que a maternidade seja hoje considerada como opcional, ainda é relacionada à identidade feminina e enaltecida pelas mulheres, tanto de classes médias quanto de baixa renda. Esse papel atribuído é tão representativo na vida 
feminina que a atuação da mulher na esfera pública traz, algumas vezes, o sentimento de culpa de não estar dedicada totalmente aos filhos (SANTOS; NOVELINO; NASCIMENTO, 2001).

Hoje a família é marcada pela heterogeneidade, onde a realidade social onde está inserida determina valores e comportamentos mutáveis, passados de geração a geração, que coexistem com modos tradicionais, porém muitas vezes em conflito (ROCHA-COUTINHO, 2006).

\subsection{Gerações}

Uma geração é composta por indivíduos que vivenciaram eventos ou fatos históricos relevantes durante seu período formativo - no fim da adolescência ou no começo da fase adulta (MANNHEIM, 1993). O que determina uma mesma posição dos nascidos em um mesmo tempo cronológico é a capacidade de testemunhar os mesmos eventos, mas, sobretudo, de processá-los de forma semelhante.

O conceito de memórias coletivas considera que pessoas com idades similares têm memórias similares de eventos históricos. A importância das memórias coletivas é esclarecer que, quando os indivíduos experimentam um fenômeno social durante o período formativo, tendem a lembrá-los mais facilmente (SHUMAN; SCOTT, 1989).

Um coorte é um grupo de pessoas que não apenas nasceram, desenvolveram e passaram por experiências semelhantes na mesma época, mas que receberam influência de eventos marcantes, especialmente no período formativo, entre 17 e 22 anos. Essas experiências compartilhadas fixam valores que moldam atitudes e comportamentos, que resistem a mudanças e fases do ciclo de vida (MEREDITH; SCHEWE; KARLOVICH, 2002).

Partindo dos coortes brasileiros, definidos por Motta, Rossi e Schewe (1999), os Babys Boomers, nascidos entre 1946 e 1964, compõem os coortes III, IV e V. Para entender melhor o que esses coortes significam para essa geração, é preciso distinguir os eventos marcantes presentes em cada coorte (Tabela 1). 


\begin{tabular}{|l|c|c|}
\hline \multicolumn{1}{|c|}{ Coorte } & Nascimento & Período formativo \\
\hline I-A era Vargas & $1913-1928$ & $1930-1945$ \\
\hline II- Pós-Guerra & $1929-1937$ & $1946-1954$ \\
\hline III- Otimismo & $1938-1950$ & $1955-1967$ \\
\hline IV- Anos de ferro & $1951-1962$ & $1968-1979$ \\
\hline V- Década perdida & $1963-1974$ & $1980-1991$ \\
\hline
\end{tabular}

Tabela 1 - Coortes Brasileiros

Adaptado de Motta, Rossi e Schewe, 1999, p.5).

O coorte III recebe o nome de Otimismo, pois os brasileiros estavam vivenciando momento de euforia, esperança e crença de um país melhor devido a liberdade política, maiores salários e rápida industrialização. Esse coorte participou da transformação da democracia para a rejeição radical à desordem. Consequentemente, seus principais valores são otimismo, aversão à desordem e aceitação de sacrifício (MOTTA; ROSSI; SCHEWE, 2002).

Os Anos de Ferro foram um período de transição no Brasil, com a chegada dos militares ao poder com a promessa de trazer ordem e segurança econômica. Entretanto, o governo acabou tornando-se impositivo e violento, houve a censura em vários setores da cultura e pessoas contrárias ao regime eram torturadas e, muitas vezes, mortas. Contudo, foi a fase do milagre brasileiro, o país cresceu economicamente, houve expansão do sistema educacional e aumento da urbanização (MOTTA; ROSSI; SCHEWE, 2002).

A Década Perdida corresponde ao período de redemocratização do País. O regime militar ainda vigorava, mas a anistia e a luta pela cidadania despontaram. A inflação devastadora assombrava toda a população; a descrença nos políticos cresceu devido a casos de corrupção no governo; o pragmatismo, individualismo e materialismo reinavam; a proliferação das drogas agravou a violência; o surgimento da AIDS provocou pânico na população e mudou o comportamento da sociedade que, sem informações adequadas sobre a doença, passou a adotar o conservadorismo (MOTTA; ROSSI; SCHEWE, 2002).

Resumidamente, os Boomers são otimistas, competitivos, buscam facilidade, economia de tempo, acreditam no progresso econômico e social, sabem trabalhar em equipe, buscam a gratificação pessoal, são adeptos às causas que defenderam - a libertação das mulheres, a diversidade, os direitos civis, as conquistas sociais e a democracia -, costumam gastar mais com comida, seguro saúde, conveniência, transporte e têm a televisão como a maior 
mediadora dos principais acontecimentos que moldaram sua personalidade geracional (LANCASTER; STILLMAN, 2002; ZEMKE; RAINES; FILIPCZAK, 2000).

Os Millennials recebem o nome por terem a maior parte dos seus integrantes vivendo o período formativo na virada do milênio. Cresceram em um mundo de racionalidade tecnológica e com livre acesso à informação, o que os torna nativos digitais por serem a primeira geração que cresceu no convívio com a internet (HOWE; STRAUSS, 2000). São resilientes, acostumados a mudanças, que consideram positivas (HOWE; STRAUSS, 2000; MEREDITH; SCHEWE; KARLOVICH, 2002), priorizam o consumo de entretenimento, de moda, de alimentação, de eletrônicos, de transportes e mudam de gostos rapidamente (GRONBACH, 2008).

Sendo assim, Boomers e Millennials vivenciaram acontecimentos marcantes distintos durante seu processo de crescimento. Portanto, seus valores, desejos, preferências, atitudes e comportamentos foram moldados de forma diferente. Cada geração gerou um perfil, um arquétipo, um modelo a ser seguido pelos demais (HOWE; STRAUSS, 2000).

\subsection{Arquétipos geracionais}

Para Howe e Strauss (2000), existem quatro arquétipos que se repetem ao longo do milênio e que correspondem a ciclos. Os ciclos seriam fases ou reviravoltas compostas por esses quatro grupos, quatro gerações, nominados arquétipos. Cada uma dessas reviravoltas refere-se a um arranjo específico dos arquétipos e cada ciclo completo representa um século. Assim, os membros de cada grupo envelhecem e entram em diferentes fases da vida, o que propicia contextos adequados para cada fase instalar-se.

O primeiro arquétipo são os Profetas, que nascem e crescem em uma fase de ápice, época disciplinada e otimista pós-guerra, onde nova ordem é instaurada e antigos valores são substituídos. No seu período formativo, criticam a ordem imposta e, ao envelhecerem, tornam-se moralistas, criticam aqueles que se tornam contrários ao script social. São identificados com Baby Boomers.

O segundo arquétipo são os Nômades, que crescem em momento de despertar, uma época passional de elevação espiritual e crítica à ordem cívica. Vivem seu período normativo alienados, em uma era abatida de reforço do individualismo e enfraquecimento das instituições. Ao amadurecem, tornam-se líderes e rígidos. São identificados como a Geração X. 
O terceiro arquétipo são os Heróis, protegidos durante a infância em uma fase de desmascaramento, onde novos valores são impostos e a antiga ordem entra em colapso. Durante seu período de formação, tornam-se jovens heroicos que trabalham em equipe para superar uma crise, uma era decisiva de revolta e substituição da ordem. Posteriormente, ao envelhecerem, costumam demonstrar arrogância e serem criticados. São identificados com os Millennials e com os Gl's.

O quarto e último arquétipo são os Artistas, superprotegidos quando crianças durante uma crise. Ao longo do seu período formativo, vivem como jovens suscetíveis; na meia idade tornam-se líderes indecisos e, ao envelhecerem, transformam-se em senhores com facilidade de se colocar no lugar do outro. Correspondem aos Silents e aos nascidos a partir de 2001.

Howe e Strauss (2000) notam que os ciclos são impulsionados a continuar pelas combinações de valores de cada geração ou arquétipo. Porém, o que importa mais é a reação da sociedade a eventos catalisadores de mudanças do que o evento em si, pois o evento catalisador simplesmente faz com que mudanças necessárias tornem-se inadiáveis. Após esses eventos, novas atitudes, valores e paradigmas são criados.

Howe e Strauss (2000) identificaram que os Millennials, por assumirem o arquétipo de heróis, são mais tradicionais, conservadores, ordeiros e cooperativos do que as gerações anteriores. Zemke, Raines e Filipczak (2000) discordam dessa visão tradicionalista e os consideram ambiciosos, questionadores, proativos, multifuncionais, preocupados com o meio ambiente e com os direitos humanos. Outros autores, como Loiola (2009), Raines (2000), Twenge (2006) e Gronbach (2008), apoiam essa visão não tradicional da geração.

Para Loiola (2009), os Millennials coexistem muito bem com as diferenças de sexo, religião, etnia e nacionalidade. Raines (2000) e Zemke et al. (2000) consideram que essa geração, por ser fruto de mães independentes, com modelos de família não convencionais, acabam sendo criados por profissionais das creches ou por avós e, por isso, aceitam a diversidade com mais facilidade. Já Twenge (2006) ressalta que a origem desse comportamento deve-se à educação e às lições de tolerância e respeito ao próximo. Por fim, Gronbach (2008) salienta que a tolerância foi herdada dos pais Boomers, que lutaram por igualdade entre homens e mulheres. 


\subsection{Papel feminino dentro das gerações}

O principal papel da mulher para as antigas gerações seria o de agradar o futuro marido, o provedor do sustento, para ser capaz de conseguir um "bom partido", da escolha dos pais e do agrado dos irmãos (BIASOLI-ALVES, 2000). Com o capitalismo houve separação da sociedade em duas esferas: o espaço privado reservado às mulheres, e o público, destinado apenas aos homens (BRUSCHINI, 2008; SAFFIOTI, 2001).

A família idealizada pela burguesia atribuiu papéis de gênero específicos, levando em consideração a divisão de espaços. A natureza feminina e a maternidade serviram como justificativa para a restrição da mulher ao mundo doméstico, entendido como lugar natural de direito e de deveres para as mulheres em função da sua condição biológica (BRUSCHINI, 2008; SAFFIOTI,2001). Elas passaram a ser preparadas para ser "rainhas do lar", mães e esposas dedicadas, o que dificultou sua inserção na esfera pública

Durante os "anos dourados" (anos 1950), apesar do aumento da participação da mulher no mercado de trabalho, essa condição de mãe, esposa e dona de casa era considerada parte da essência feminina e destino natural de toda mulher de "família". O preconceito era enorme, pois muitos acreditavam que a mulher não conciliaria suas funções primordiais - casa, filhos e marido - e colocaria em risco o tão superestimado casamento (BRUSCHINI, 2008; BIASOLI-ALVES, 2000; SAFFIOTI, 2001).

A industrialização, a urbanização e o aumento do nível de escolaridade possibilitaram a ingressão no mercado de trabalho e consequentemente a melhor transição da mulher da esfera privada para a pública. Junto com a criação da pílula contraceptiva, transformaram as relações familiares e de gênero. Estudos realizados no Brasil (ARAÚJO; SCALON, 2005; ROCHACOUTINHO, 2004) evidenciam que os trabalhos domésticos continuam sendo um grande obstáculo para a inserção da mulher na vida social, pois, mesmo exercendo atividade fora do lar, precisam desdobrar-se para as conciliar com os afazeres domésticos. Hoje, além de ser capaz de buscar independência financeira, valorização profissional e satisfação conjugal, a nova mulher precisa administrar o lar, educar os filhos e socializar.

O novo papel da mulher, a profissional, inaugurou modificação cultural marcada por contradições. Para alguns autores (MADALOZZO et al. 2010; POESCHL, 2000), a classe social a que pertence exerce forte influência em como a nova mulher lida com os obstáculos. As mulheres de classes 
economicamente privilegiadas têm função mais administrativa, delegando os trabalhos domésticos para empregadas ou babás, enquanto que as de baixa renda, por precárias condições financeiras, que a impedem de repassar tais tarefas, realizam as duas atividades, o trabalho fora e o dentro de casa, ficando com tempo restrito para descanso e lazer.

Essa pluralidade de papéis fez Lipovetsky (2000) discutir o desenvolvimento de uma "terceira mulher". A primeira foi a sedutora, desprezada e depreciada. A segunda era bajulada, idealizada pelo homem e subordinada a ele. A terceira busca seu novo caminho, a independência, não está restrita ao lar, tem acesso à educação e ao trabalho e tem liberdade de escolha no matrimônio e na maternidade.

A Disney transmite esses papéis femininos nas personagens, com identificação de posicionamentos ideológicos e mudanças culturais, procurando estar de acordo com os papéis aceitos pela sociedade contemporânea (BETTLHEIM, 2014). Apesar de suas animações atuais mostrarem um comportamento social diferente das primeiras animações, a segunda mulher de Lipovetsky (2000), idealizada pela sociedade patriarcal, ainda é muito presente na mídia.

\subsection{Marca e personagens a ela associadas}

Ao ser capaz de difundir e representar papéis sociais, uma marca torna-se mais do que um produto. O monitoramento e alinhamento de suas personagens a novas tendências e mudanças socioculturais são necessários para "aumentar a lembrança de marca, facilitar a formação de associações de marcas fortes, favoráveis e exclusivas e gerar julgamentos e sentimentos positivos sobre a marca" (KELLER, 2006, p. 91).

Redes associativas de memória, ou redes de associações mentais, são criadas a partir dos significados da marca. Cada marca formará, assim, associações próprias na mente de cada consumidor, de acordo com experiências passadas, crenças, valores e atitudes. Neste modelo, conhecido como ativação expandida de Schmitt e Simonson (2002), a marca, metaforicamente, ocupa uma espécie de arquivo na mente, que é acessado quando ela é ativada. Neste arquivo estão contidas informações e referências que serão transformadas em conhecimento e despertarão afeto e atitudes, positivas ou negativas, em relação à marca. Os consumidores tornam-se construtores de significados e não apenas receptores passivos das marcas. 
Por terem vivenciado diferentes experiências, a forma como os consumidores as absorve e as armazena não são iguais: a marca adquire significado distinto para cada consumidor. O consumo de imagens, de fatos e de informações procura estimular a mudança e a história, assim como os mitos. Filmes animados das princesas Disney são verdadeiros mitos modernos da indústria cultural, que legitimam identidades sociais e de gênero com suas personagens, fazendo com que consumidores e produtores tenham relações de poder. Ao representarem o desejável e o indesejável na sociedade, por meio de cenas e falas dos personagens, produzem e legitimam representações sociais, enquanto os consumidores passam a legitimá-las e produzi-las ao reproduzir, no seu dia a dia, os comportamentos das personagens de que tanto gostam (PIRES, 2009).

Este sucesso da cultura midiática, para Lipovetsky (1989), deve-se à capacidade de oferecer uma mudança de ares, de lazer, de esquecimento da vida real para viver um sonho. "Consumimos em espetáculo aquilo que a vida real nos recusa” (p. 221). Pela ótica do consumo, a mídia assume papel relevante na vida e na formação de valores, comportamentos e atitudes, através da transmissão de estereótipos que reforçam padrões considerados ideais. $O$ entretenimento, associado a lembranças da infância e a outros meios da cultura popular, transmite mensagens político-culturais intrínsecas, que funcionam como referências influenciadoras dos pensamentos, valores, ações e gostos daqueles que os consomem. Por serem capazes de oferecer significados e exercerem influência, os filmes infantis atuam como pedagogias culturais (GIROUX, 1995).

O termo pedagogia cultural refere-se a imagens e fenômenos culturais que educam as pessoas, sem ser uma atividade ou instituição socialmente reconhecida por esse fim. Assim como a escola, instituição tradicional de aprendizagem, as pedagogias culturais estão qualificadas para educar, produzir, organizar e difundir conhecimentos específicos. Contudo, seu ensino está associado a prazer, a consumo e a fantasia. As produções da marca Disney, por apresentarem histórias mágicas com personagens encantados, atuam como verdadeiras "máquinas educadoras", que ensinam que comportamentos, ações e espaços podem e devem ser ocupados por meninos e meninas (GIROUX, 1995).

As personagens de marca podem ser celebridades ou personagens criadas. As mascotes fazem parte do mix de identidade das marcas e são um tipo especial de personagens de marca. Podem ser animais, humanoides - por se assemelharem mais com a figura humana - ou um produto antropomorfizado. São responsáveis por criarem elos afetivos, pois se os "consumidores tiverem 
um sentimento forte em relação a uma mascote, irão muito provavelmente criar percepções favoráveis acerca dos produtos ou organização com os quais aquela mascote está associada" (CÔRTE-REAL; LENCASTRE, 2012, p. 3).

As personagens são construídas a partir de vários elementos - gênero, classe social, etnia, grau de formação, religião/crenças e geração -, que influenciam na caracterização e no modo de pensar, de falar, valores e emoções (SEGER, 2006). Seus criadores podem selecionar que atributos são mais convenientes e a vincularem a um único produto, ou a uma única marca. Isso as faz serem vantajosas em relação ao uso de celebridades, pois celebridades conservam traços característicos da sua personalidade e normalmente estão ligadas simultaneamente a várias marcas (CÔRTE-REAL; LENCASTRE, 2012).

Para McCracken (2005), a celebridade pode exercer quatro papéis: o de testemunho, endossar, ser ator ou ser porta-voz. Ao testemunhar, atesta a qualidade do produto baseado no seu uso. No endosso, emprestam seu nome para ser vinculado junto à marca. Como ator, retrata o produto como sendo responsável por ele e, como porta-voz, representa a marca por um período estabelecido. $O$ endosso por celebridades se apoia na credibilidade e na atratividade da fonte. Ao exibir expertise e confiabilidade, a fonte torna-se crível. Para se tornar atrativa, depende da familiaridade, da similaridade ou da simpatia com o consumidor. Um endosso é bem-sucedido quando as características do endossante - classe, gênero, estilo de vida, ciclo de vida, status, personalidade, e papéis - são associadas aos significados pretendidos do produto.

\subsection{Princesas Disney}

Para melhor compreensão cronológica da criação das princesas Disney e do papel da mulher na sociedade, as princesas podem ser classificadas em três grupos: as princesas clássicas, as rebeldes e as contemporâneas (BREDER, 2013; FERREIRA, 2015; DRAEGER, 2015).

As princesas clássicas eram a personificação do papel tradicionalista da mulher, enaltecida, idolatrada e idealizada pelos homens, que precisava ser esposa e mãe dedicada, bela, gentil, bondosa, romântica, ligada aos afazeres domésticos e que sonhava com o príncipe encantado que as salvaria dos perigos (ROZARIO, 2004; SILVERMAN, 2009).

Branca de Neve, Cinderela e a Bela Adormecida fazem parte desse grupo. Elas exercem dois papéis femininos, o de grande mãe e de donzela. A grande mãe é a imagem da mulher como eterno ventre, provedora, protetora e 
responsável por toda forma de vida. A donzela é o arquétipo dinâmico que representa o outro lado da grande mãe, o lado da beleza sedutora e fascinante (RANDAZZO, 1996).

As características da grande mãe podem ser identificadas na relação protetora e cuidadora das princesas. $O$ arquétipo da donzela, por sua vez, pode ser observado na valorização da beleza em todas as princesas e no sonho de encontrar o príncipe encantado e o amor eterno (RANDAZZO, 1996). A mulher era a descrição da "rainha do lar" - padrão de mulher da década de 1950 -, a mais bela, bondosa, gentil, protetora e que cumpre as tarefas domésticas sem reclamar (KRAUSE, 2014).

Ao príncipe é atribuído o papel heroico de resgatar a mulher da sua vida miserável para transformá-la numa princesa. A menina aprende desde cedo que, para ser feliz, é preciso ser amada.

"A mulher é a Bela Adormecida no bosque, Cinderela, Branca de Neve, a que recebe e suporta. Nas canções, nos contos, vê-se o jovem partir aventurosamente em busca da mulher; ele mata dragões, luta contra gigantes; ela acha-se encerrada em uma torre, um palácio, um jardim, uma caverna, acorrentada a um rochedo, cativa, adormecida: ela espera" (BEAUVOIR, 1967, p. 33).

Além disso, essas três princesas apresentam características como pele branca, voz graciosa, cabelos bem arrumados e bondade. Fica clara a relação entre a aparência das princesas e a bondade, uma vez que as bruxas e as vilãs são retratadas como feias e sem coração. Existe, ainda, a associação entre cabelos e algumas qualidades. Cabelos loiros remetem à bondade, sua luminosidade é comparada com a beleza e o brilho do loiro, enquanto cabelos escuros, crespos e despenteados são relacionados ao selvagem, ao desleixo e à maldade. Cabelos longos indicam feminilidade, cortá-los denota liberdade do padrão e acaba influenciando estranhamento nos demais (WARNER, 1999).

A segunda geração de princesas, representadas por Ariel, Jasmine, Bela, Pocahontas e Mulan, tem como principal característica o desvio das regras previamente impostas e a valorização da independência (ROZARIO, 2004; SILVERMAN, 2009). Elas são menos passivas, não ficam à espera do príncipe encantado; pelo contrário, lutam por eles e salvam suas vidas. Essas características fazem jus à época em que foram criadas e lançadas, nas décadas de 1980 e 1990.

Nessas princesas pode ser identificado o papel da guerreira-heroína, uma conquista importante do movimento feminista, que abandona tradicionais 
padrões femininos para tornar-se independente, corajosa, forte, defensora da verdade e da justiça. Elas personificam esse arquétipo ao se tornarem mais corajosas, questionadoras e não dependentes de príncipes encantados (RANDAZZO, 1996).

Com o aumento da amplitude de papéis de gêneros exibidos nos filmes, os personagens tornam-se andróginos; personagens femininas adquirem algumas características tidas como masculinas e vice-versa. Ariel foi a primeira princesa a desafiar o tradicional papel do gênero feminino, por ser independente e ter-se rebelado contra o pai. No entanto, ainda tinha muitos estereótipos característicos das princesas clássicas, como medo, afeição e aparência física, enquanto o comportamento do príncipe misturou estereótipos tradicionais masculinos, como a bravura, e outros femininos, como a afetividade e a emoção (ENGLAND; DESCARTES; COLLIN-MEEK, 2011).

As novas princesas, Tiana, Rapunzel, Mérida, Elsa e Anna e Moana, protagonistas dos filmes "A Princesa e o Sapo" (2009), "Enrolados" (2011), "Valente" (2012), Frozen (2014) e "Moana - um mar de aventuras" (2017), não estão à procura do príncipe encantado. São independentes e buscam realizar seus sonhos, sem ter no casamento a fuga da realidade. $O$ encantamento e a magia continuam presentes, mas o "felizes para sempre" perdeu espaço para finais mais realistas e alcançáveis (ENGLAND et al. 2011).

Tiana, a primeira princesa negra da Disney, evidencia que sonhar e trabalhar duro permitirá fazer o que quiser. O filme apresenta um príncipe mais andrógino, que mostra emoção e carinho com frequência, e uma princesa batalhadora e persistente, capaz de realizar seus sonhos sem a ajuda do príncipe. O aspecto mais distintivo desse filme é o casamento inter-racial (BREDER, 2013; FERREIRA, 2015; DRAEGER, 2015).

No filme Frozen (2014) pode-se observar a beleza retratada de forma diferente dos antigos filmes. A princesa Anna não é uma mulher totalmente perfeita, sempre com cabelos arrumados e pele lisa; pelo contrário, em várias cenas aparece despenteada e despreocupada com a aparência. Ademais, o vilão não segue o padrão de feiura dos outros filmes, ele é o príncipe encantado que surpreende ao se revelar uma pessoa má e interesseira. Além disso, o paradigma do casamento e da felicidade eterna é quebrado e o amor fraterno entre irmãs é legitimado (BREDER, 2013; FERREIRA, 2015; DRAEGER, 2015). 


\section{Método}

Neste capítulo, serão apresentadas as decisões tomadas para a realização da investigação. A pesquisa é de natureza exploratória, por meio de abordagem fenomenológica, empregando entrevistas de caráter dialógico (THOMPSON; LOCANDER; POLLIO, 1989) que permitiram às participantes descrever experiências vividas sem a rigidez imposta por roteiro pré-definido.

As entrevistadas foram selecionadas inicialmente por conveniência e, posteriormente, por snowballing. Algumas conhecidas da pesquisadora foram escolhidas previamente e, após os encontros, indicavam outras pessoas que acreditavam corresponderem ao perfil desejado (GROENEWALD, 2004). Para entender melhor cada entrevistada e o arranjo familiar em que viviam, foram feitas perguntas preliminares para saber seu estado civil, se eram mães e/ou avós, quantos filhos e/ou netos tinham, qual a escolaridade e em qual bairro do Rio de Janeiro moravam. Para preservar o anonimato, nomes fictícios foram usados. Para iniciar o diálogo, foi feita uma pergunta a cada entrevistada "Quando falo em Disney, o que vem à sua mente?"

Groenewald (2004) recomenda que a busca de novas entrevistas continue até o tópico estar saturado, ou seja, quando as vozes escolhidas não introduzem novas perspectivas. Seguindo essa recomendação, foram conduzidas dezesseis entrevistas, oito mulheres de cada geração, entre 25 e 35 anos (geração Millennials) e 50 e 65 anos (geração Baby Boomer). Duas de Duque de Caxias, município da Baixada Fluminense do Rio de Janeiro; duas da zona norte do município do Rio de Janeiro, (uma do Complexo da Maré e outra da Penha); uma de Benfica, na zona central; duas de Engenheiro Pedreira, distrito de Japeri e nove da zona oeste: oito da Gardênia Azul, em Jacarepaguá, e uma em Campo Grande. A escolha de mulheres de baixa renda deve-se ao fato de essa classe ser considerada como mais tradicional nos arranjos familiares, tendo o patriarcalismo como organização familiar mais marcante (ROCHA-COUTINHO, 2006).

Como pré-requisito para a entrevista, era preciso estar familiarizada com filmes antigos da Disney (como Cinderela) e novos (como Frozen). Esses dois filmes foram escolhidos por marcarem as gerações Baby Boomers e Millennials e retratarem o papel da mulher à época de cada lançamento. Cinderela (1950) é a clássica representação da mulher que precisa do príncipe para ser salva. Frozen (2014) quebra o paradigma do amor verdadeiro ser apenas entre um 
homem e uma mulher, estabelecendo a perspectiva do bem-querer entre irmãs. Para melhor entendimento, a história dos filmes será revisitada a seguir.

\subsection{Cinderela}

Um dos grandes sucessos dos filmes da Disney, foi lançado em 1950, após o fim da Segunda Guerra Mundial, como uma grande aposta dos estúdios para superar prejuízos provocados pela crise econômica. A animação foi uma adaptação do conto de Charles Perrault ${ }^{2}$ de 1967 e da versão escrita pelos Irmãos Grimm ${ }^{3}$. O seu lançamento reanimou as finanças da empresa, garantiu vida longa à marca e se tornou um dos clássicos.

$\mathrm{Na}$ versão original de Cinderela, para que seus pés coubessem no sapatinho de cristal, as irmãs postiças têm um comportamento grotesco: uma corta os dedos do pé e a outra corta o calcanhar. Porém, o esforço foi em vão, já que o príncipe é avisado de que o sapatinho estava manchado de sangue e não aceita nenhuma das duas como esposa. Nesse enredo, não existe fada madrinha. Mesmo assim, o príncipe consegue encontrar a sua verdadeira amada e, no dia do casamento com Cinderela, as irmãs têm os olhos furados por pássaros quando tentam chegar à cerimônia. A história encerra-se com Cinderela quebrando o pescoço da madrasta má com a tampa de um baú.

Na obra cinematográfica da Disney, a história é mudada e ganha uma versão para crianças. Cinderela, ao perder o pai, passa a morar com a madrasta e suas filhas e acaba tornando-se a criada da casa, sendo muito maltratada pelas três. Sua vida muda quando o rei decide fazer um baile em homenagem ao filho, na esperança de encontrar sua futura esposa. Mesmo com todo o esforço das irmãs e da madrasta, para impedir que Cinderela consiga ir ao baile, ela consegue ir graças a uma fada madrinha, que a ajuda. No baile, o príncipe apaixona-se por ela, que acaba perdendo o sapato de cristal ao ir embora. $\mathrm{O}$ príncipe, então, começa a busca por todas as damas, para saber em qual delas o sapato serviria. Por fim, Cinderela é encontrada, eles se casam e vivem felizes para sempre.

A Gata Borralheira, expressão originada a partir do conto Cinderela, pode ser compreendida como a descrição da mulher do lar, a mulher que se

2 França, 1628-1703. Conhecido como "Pai da Literatura Infantil". infantis.

${ }_{3}$ Alemanha. Jacob -1785-1863. Wilhelm -1786-1859. Conhecidos pelas fábulas 
encaixava nos padrões da época. Na década de 1950, a América do Norte estava em ascensão, enquanto a Europa tentava com dificuldade reerguer-se da guerra. O modo americano de viver, o famoso "American Way of Life", era disseminado para o restante do mundo. A mulher era quem executava as tarefas domésticas e era conhecida como a "rainha do lar" (KRAUSE, 2014).

\subsection{Frozen}

Inspirado no conto de fadas A Rainha das Neves, de Hans Christian Andersen ${ }^{4}$, Frozen foi lançado em 2014 no Brasil. A trama gira em torno de duas irmãs, Anna e Elsa. Elsa tem o poder de congelar objetos e pessoas com um simples toque. Quando crianças, seus pais as separam e as mantiveram dentro do castelo, pois Elsa havia machucado Anna e eles tinham medo de revelar o poder da filha. No entanto, uma fatalidade acaba matando o rei e a rainha, e Elsa, por ser a mais velha, é coroada e todos a acabam conhecendo.

Inicialmente, o filme se assemelha com um conto de fadas, com princesas tradicionais. Porém, uma cena e o final chamam a atenção: no dia da coroação de Elsa, Anna conhece um jovem príncipe, Hans, que a pede em casamento. Ingênua, ela acredita estar apaixonada, mas é impedida por sua irmã, que a alerta dizendo que não pode casar-se com um homem que acabou de conhecer. Essa fala contraria o tradicional discurso da Disney, em que a bela princesa encontra o príncipe e se apaixona perdidamente à primeira vista.

A história desenrola-se com Elsa revelando seu poder e fugindo para proteger o reino. Anna decide ir ao seu encontro, acaba sendo atingida por Elsa e tem o seu coração congelado. A velha história de somente o amor verdadeiro poderá salvar, presente nos primeiros enredos, retorna. Entretanto, diferentemente das princesas tradicionais, o verdadeiro amor não é por um homem, mas sim o amor fraterno entre irmãs. Anna, para proteger a irmã, entra na mira da espada e acaba sendo atingida. Elsa chora abraçada com a irmã morta em seus braços e o amor verdadeiro de uma pela outra faz com que Anna volte à vida.

Nesse filme, a Disney quebra um paradigma presente em seus desenhos anteriores: a inimizade e a inveja entre duas mulheres, como em Cinderela, Branca de Neve, e outros filmes. Além disso, Anna é traída pelo príncipe, que se mostra interesseiro, e salva sua irmã num ato de amor, aceitando-a como ela é,

\footnotetext{
${ }^{4}$ Escritor e poeta dinamarquês de histórias infantis (1805-1875).
} 
mostrando que Elsa pode viver no reino e ser aceita por todos. O filme é reflexo da conquista de novos papéis pelas mulheres, que não encontram no casamento a única solução para a felicidade e ascensão social.

\subsection{Condução das entrevistas}

As entrevistas foram conduzidas nas residências das entrevistadas. Além da escuta cuidadosa, foram também considerados elementos corporais e gestuais. Todas as entrevistas foram gravadas com o consentimento das participantes e posteriormente transcritas literalmente. Por ser um tema que envolve histórias pessoais, as identidades não são reveladas, criando-se nomes fictícios.

A condução dos encontros foi definida pela entrevistada, relatando experiências de vida, opinião sobre os filmes, personagens e marca, e o entendimento do seu papel na sociedade como mulher. As indagações surgiram de forma natural, evitando a utilização da expressão como por quê, para não gerar racionalizações e respostas na defensiva (THOMPSON et al. 1989). Através do diálogo, relatos de vivências foram incentivados, o que provocou emoções em algumas ao expor momentos sofridos de suas vidas, levando a pesquisadora a perguntar se queriam que a entrevista fosse interrompida, o que não aconteceu. Foi interessante notar que os dois filmes escolhidos como marcantes de cada geração, Cinderela e Frozen, foram mencionados espontaneamente por todas as entrevistadas, tornando-se referenciais para o estudo.

A perspectiva fenomenológica adotada não visa generalizar resultados. O que se pretendeu foi chegar a uma compreensão da percepção das entrevistadas em relação à posição da mulher frente ao papel desempenhado pelas princesas da Disney no contexto apreendido por elas. Esta perspectiva reconhece a intersubjetividade que ocorre entre o participante e o pesquisador, que possibilita a apreensão de forma compartilhada de crenças e experiências vividas. Por ser uma pesquisa feita na casa das participantes, situações inesperadas podem acontecer e perturbar a condução da entrevista (ZIKMUND, 2006). Essas interferências atingem tanto o entrevistado quanto a entrevistadora, porém fogem do controle da pesquisadora que, no caso, precisou saber lidar com elas, sem quebrar a confiança conquistada. 


\section{Explicitação dos dados}

A fenomenologia utiliza "explicitação de dados" em lugar de "análise de dados", pois entende que "análise" significa quebrar em partes e "explicitação" implica numa investigação do todo, sendo todo o fenômeno estudado e não apenas partes dele (GROENEWALD, 2004).

As entrevistas foram divididas de acordo com a geração de cada participante e dois blocos foram criados: geração Baby Boomer e geração Millennial. De posse das transcrições, a leitura dos conteúdos foi feita seguindo a categorização das princesas com as quais as mulheres mais se identificavam e por padrões e temas recorrentes.

São apresentados, em primeiro lugar, o perfil (Quadro 1), os momentos de vida e as percepções da realidade das entrevistadas sobre a marca e sobre as personagens, ao relembrarem os filmes da Disney. Por se tratar de tema que faz recordar ocasiões passadas, pode ser muito pessoal e delicado, portanto buscou-se deixar as participantes o mais confortável possível e acolhidas com uma escuta muito atenta.

As categorias de família, marca e personagens foram apropriadas para a "mostração" das vivências das participantes e dão continuidade ao capítulo.

\subsection{Perfil das entrevistadas}

Para melhor compreensão do quadro, faz se a uma breve apresentação das participantes, começando pelo grupo Baby Boomer (Gabriela, Ilda, Carla, Amanda, Irene, Maria, Iza e Augusta). Nesse grupo temos três solteiras, duas casadas, uma divorciada e duas viúvas pensionistas. Somente uma conseguiu fazer um curso técnico e outra completou o ensino médio, quatro não terminaram o ensino médio, uma completou o fundamental e outra não o completou. Só uma não teve filhos, apenas uma não mora em casa própria e duas são donas de casas. Com isso, podemos observar que o discurso da época do papel da mulher como sendo dona de casa, mãe e esposa não se mantém. Entretanto, estudar não pareceu ser prioridade para elas, devido a necessidade de trabalhar desde cedo. 


\begin{tabular}{|c|c|c|c|c|c|}
\hline Nome/ldade & Geração & Escolaridade & $\begin{array}{c}\text { Estado } \\
\text { Civil }\end{array}$ & Ocupação & Bairro \\
\hline $\begin{array}{l}\text { Gabriela } \\
51 \text { anos }\end{array}$ & $\begin{array}{c}\text { Baby } \\
\text { Boomer }\end{array}$ & Técnico & Solteira & Enfermeira & $\begin{array}{l}\text { Campo } \\
\text { Grande }\end{array}$ \\
\hline $\begin{array}{c}\text { llda } \\
50 \text { anos }\end{array}$ & $\begin{array}{c}\text { Baby } \\
\text { Boomer }\end{array}$ & $\begin{array}{c}\text { Ensino médio } \\
\text { completo }\end{array}$ & Solteira & Doméstica & $\begin{array}{c}\text { Engenheiro } \\
\text { Pedreira }\end{array}$ \\
\hline $\begin{array}{c}\text { Carla } \\
59 \text { anos }\end{array}$ & $\begin{array}{c}\text { Baby } \\
\text { Boomer }\end{array}$ & $\begin{array}{l}\text { Ensino médio } \\
\text { incompleto }\end{array}$ & Viúva & Dona de casa & $\begin{array}{c}\text { Gardênia } \\
\text { Azul }\end{array}$ \\
\hline $\begin{array}{l}\text { Amanda } \\
53 \text { anos }\end{array}$ & $\begin{array}{c}\text { Baby } \\
\text { Boomer }\end{array}$ & $\begin{array}{l}\text { Ensino médio } \\
\text { incompleto }\end{array}$ & Casada & Doméstica & Penha \\
\hline $\begin{array}{c}\text { Irene } \\
50 \text { anos }\end{array}$ & $\begin{array}{l}\text { Baby } \\
\text { Boomer }\end{array}$ & $\begin{array}{c}\text { Ensino } \\
\text { fundamental } \\
\text { completo }\end{array}$ & Solteira & Doméstica & $\begin{array}{c}\text { Engenheiro } \\
\text { Pedreira }\end{array}$ \\
\hline $\begin{array}{c}\text { Maria } \\
52 \text { anos }\end{array}$ & $\begin{array}{l}\text { Baby } \\
\text { Boomer }\end{array}$ & $\begin{array}{c}\text { Ensino } \\
\text { fundamental } \\
\text { incompleto }\end{array}$ & Casada & $\begin{array}{l}\text { Cozinheira de } \\
\text { creche }\end{array}$ & $\begin{array}{l}\text { Gardênia } \\
\text { Azul }\end{array}$ \\
\hline $\begin{array}{c}\text { Iza } \\
50 \text { anos }\end{array}$ & $\begin{array}{c}\text { Baby } \\
\text { Boomer }\end{array}$ & $\begin{array}{l}\text { Ensino médio } \\
\text { incompleto }\end{array}$ & Viúva & Dona de casa & Benfica \\
\hline $\begin{array}{l}\text { Augusta } \\
55 \text { anos }\end{array}$ & $\begin{array}{c}\text { Baby } \\
\text { Boomer }\end{array}$ & $\begin{array}{c}\text { Ensino } \\
\text { fundamental } \\
\text { completo }\end{array}$ & Divorciada & $\begin{array}{c}\text { Acompanhante } \\
\text { de idoso }\end{array}$ & $\begin{array}{l}\text { Gardênia } \\
\text { Azul }\end{array}$ \\
\hline $\begin{array}{c}\text { Paula } \\
25 \text { anos }\end{array}$ & Millennial & $\begin{array}{c}\text { Ensino médio } \\
\text { completo }\end{array}$ & Casada & Babá & $\begin{array}{c}\text { Gardênia } \\
\text { Azul }\end{array}$ \\
\hline $\begin{array}{c}\text { Flavia } \\
32 \text { anos }\end{array}$ & Millennial & $\begin{array}{c}\text { Ensino médio } \\
\text { completo }\end{array}$ & Casada & Dona de casa & Imbariê \\
\hline $\begin{array}{c}\text { Erica } \\
35 \text { anos }\end{array}$ & Millennial & $\begin{array}{c}\text { Ensino } \\
\text { superior } \\
\text { completo } \\
\end{array}$ & Casada & Professora & $\begin{array}{l}\text { Gardênia } \\
\text { Azul }\end{array}$ \\
\hline $\begin{array}{l}\text { Tatiana } \\
33 \text { anos }\end{array}$ & Millennial & $\begin{array}{c}\text { Ensino } \\
\text { superior } \\
\text { completo }\end{array}$ & Casada & Publicitária & $\begin{array}{l}\text { Gardênia } \\
\text { Azul }\end{array}$ \\
\hline $\begin{array}{c}\text { Luísa } \\
25 \text { anos }\end{array}$ & Millennial & $\begin{array}{l}\text { Ensino médio } \\
\text { incompleto }\end{array}$ & Casada & Vendedora & $\begin{array}{l}\text { Duque de } \\
\text { Caxias }\end{array}$ \\
\hline $\begin{array}{c}\text { Leila } \\
25 \text { anos }\end{array}$ & Millennial & $\begin{array}{l}\text { Ensino médio } \\
\text { completo }\end{array}$ & Casada & Boleira & $\begin{array}{c}\text { Gardênia } \\
\text { Azul }\end{array}$ \\
\hline $\begin{array}{l}\text { Juliana } \\
27 \text { anos }\end{array}$ & Millennial & $\begin{array}{c}\text { Ensino } \\
\text { superior } \\
\text { cursando } \\
\end{array}$ & Solteira & Contadora & $\begin{array}{l}\text { Complexo } \\
\text { da Maré }\end{array}$ \\
\hline $\begin{array}{c}\text { Ana } \\
29 \text { anos }\end{array}$ & Millennial & $\begin{array}{l}\text { Ensino médio } \\
\text { completo }\end{array}$ & Solteira & $\begin{array}{c}\text { Vendedora de } \\
\text { loja }\end{array}$ & $\begin{array}{c}\text { Gardênia } \\
\text { Azul }\end{array}$ \\
\hline
\end{tabular}

Gabriela tem 51 anos, fez curso técnico de enfermagem e trabalha na profissão; tem um filho e uma neta, mora em casa própria em Campo Grande e é solteira.

Ilda tem 50 anos, é solteira, não tem filhos, mas trata os sobrinhos como se fossem seus filhos. Conseguiu terminar o ensino médio, trabalha como doméstica em Copacabana e mora no mesmo terreno dos pais, em Engenheiro Pedreira. 
Carla é viúva e pensionista, com 59 anos é a mais velha do grupo, é dona de casa, tem onze filhos e seis netos, mora na Gardênia Azul em casa própria e não completou o ensino médio.

Amanda trabalha como empregada doméstica, tem 53 anos, três filhos e três netos, ensino médio incompleto. Mora no bairro da Penha com o marido, um filho, nora e duas netas.

Irene também trabalha como empregada doméstica, tem 50 anos, não conseguiu terminar o ensino médio, nunca se casou, tem uma filha e mora com ela, os pais e irmãos em Engenheiro Pedreira.

Maria é casada, tem 52 anos, não conseguiu completar o ensino fundamental, tem três filhos e cinco netos, trabalha como cozinheira de creche e mora em casa própria com o marido na Gardênia Azul.

Iza tem 50 anos, é viúva pensionista, dona de casa, não completou o ensino médio, tem uma filha com quem mora em casa própria, em Benfica.

Augusta é divorciada, tem três filhos e sete netos, tem 55 anos, ensino fundamental completo, trabalha como acompanhante de idoso e, com muito esforço, conseguiu dividir o terreno na Gardênia Azul para fazer quatro casas, uma para ela e as outras para os filhos.

Percebe-se diferenças das Baby Boomers em relação às Millennials (Paula, Flavia, Erica, Tatiana, Luísa, Leila, Juliana e Ana). Diferentemente das Boomers, as entrevistadas da geração Millennials têm níveis mais altos de educação acadêmica: uma tem pós-graduação e duas ingressaram no ensino superior, uma já completou o curso e a outra está na fase final. Quatro têm o ensino médio completo e apenas uma não conseguiu completá-lo. Observa-se que o número de casadas é maior do que na geração Baby Boomers: seis casadas, uma solteira e uma divorciada. Embora a maternidade tenha ganhado outra visão para essa geração, sendo opcional e não obrigatória, somente uma entrevistada não tem filhos.

Paula tem 25 anos, é babá, tem uma filha que não vive com ela, tem ensino médio completo, é casada e mora com o marido, na Gardênia Azul.

Flavia acabou de ter o segundo filho e por isso não trabalha atualmente, tem 32 anos, ensino médio completo e mora de aluguel com o marido e filhos, em Imbariê.

Erica tem curso de pós-graduação em história, tem 35 anos, é professora de escola pública, tem um filho. Mora com ele e o marido em casa própria, no bairro de Gardênia Azul. 
Tatiana também é morada de Gardênia Azul, paga aluguel, tem 33 anos, ensino superior em Comunicação Social, trabalha como publicitária. Casada e tem um filho.

Luísa trabalha vendendo roupa pelo bairro onde mora, em Duque de Caxias. Não conseguiu terminar o ensino médio, tem 25 anos, é casada, mãe de uma menina e mora de aluguel.

Leila também tem 25 anos, faz doces por encomenda, tem o ensino médio completo, dois filhos e mora com eles e o marido em casa própria em Gardênia Azul.

Juliana trabalha na área financeira de uma empresa, tem 27 anos e está terminando o ensino superior, é solteira, sem filhos e mora com os pais no Complexo da Maré.

Ana é mãe de três meninas, tem 29 anos, é divorciada, tem o ensino médio completo, trabalha como vendedora de loja e mora em casa dada pela mãe, em Gardênia Azul.

\subsection{Família}

Nas entrevistas do grupo Baby Boomers foi possível observar que a expansão da escolarização e da profissionalização das mulheres não existiu. Vaitsman (1994) chama a atenção para o fato de essa situação ser um privilégio das mulheres das classes médias. Somente Ilda tem o ensino médio completo e somente Gabriela conseguiu ingressar no curso técnico de sua preferência, trabalhando na área. Ao relatarem sua infância e criação, as mulheres da geração Baby Boomers evidenciaram que o estudo teve que ficar em segundo plano, pois a situação financeira dos pais as obrigou a trabalhar desde cedo. Seu aprendizado foi voltado para a cozinha, tarefas domésticas e cuidado com crianças, para se tornarem boas donas de casa e mães.

Interessante destacar que a falta de formação acadêmica profissional não vem impedindo que elas compreendam a diferença entre o contexto social econômico que atravessaram e o atual. Sem negarem a valorização dos cuidados referentes à família, conseguem perceber uma nova posição para a mulher.

"Independente da classe social, independente da situação, elas estão correndo atrás, buscando seus sonhos, antigamente era impossível uma pessoa de baixa renda 
numa faculdade, hoje em dia tamos ai né, independente da situação que o país se encontra, mas estamos ai, tem várias pessoas na faculdade que se formaram graças a Deus. É isso, entendeu? (Irene).

As entrevistadas Millennials relataram o esforço dos pais, principalmente das mães, para que estudassem e tivessem vida melhor do que as suas. Só Luísa não conseguiu completar o ensino médio. Ela perdeu a mãe muito cedo e acabou sendo criada pela avó, na roça da Paraíba. Lá, não tinha perspectiva de mudança de vida e a falta de interesse pelos estudos a fez abandonar a escola para se dedicar àquilo que considerava importante, a família. Sua infância foi marcada por papéis muito bem definidos para a mulher: não podia usar roupas curtas, tinha que ficar em casa e só ganhava brinquedos de cor rosa ou relacionados ao trabalho doméstico. Com 18 anos, veio para o Rio de Janeiro em busca de um trabalho e vida melhor do que a da roça. Aqui encontrou uma sociedade com pensamentos modernos em relação à mulher. Hoje, considera-se uma vitoriosa, por ter conseguido comprar casa própria com seu esforço e trabalho. Interessante observar no relato a seguir a linguagem de Luísa, que deixa claro que acompanha os debates que estão presentes na compreensão das relações de família e gênero.

\footnotetext{
"Nós mães, eu tenho uma filha, você acha que, até... de mim mesmo, porque a gente, a gente é criado no mundo, assim, muita gente vem de uma família que não é feminista. Hoje, né... a gente tá aprendendo a ser feminista, porque antes a gente não era, pelo menos eu não era, eu vim de uma que... a mulher teria que ficar em casa, não podia trabalhar ou a mulher não podia vestir uma roupa curta, quando ganhava brinquedo, quem tem irmão sabe disso, que é especifico, o carrinho ou bola pra menino e pra menina é boneca ou panelinha, e porque não pode dar panelinha pro homem, será que ele não pode cozinhar também" (Luísa).
}

Diferente das Boomers, o ensino superior já é realidade para algumas dessas entrevistadas. Erica e Tatiana já o completaram e trabalham na área que escolheram; Juliana está terminando o curso escolhido, mas já está trabalhando 
na área de sua carreira. Mesmo sendo difícil, as entrevistadas de baixa renda buscaram ingressar no ensino superior.

O arranjo familiar tradicional, para Heilborn (1995), Rocha-Coutinho (2006) e Parente (2008), com o homem sendo o chefe de família e provedor, e a mulher sendo mãe e esposa, parece ter perdido espaço para novos arranjos, na visão das entrevistadas. Da geração Baby Boomers, somente Carla e Iza não trabalham fora, pois são viúvas e vivem da pensão deixada pelo marido. As demais precisam trabalhar, sendo a única fonte de renda para complementar a renda familiar. Por não terem formação especializada, acabam buscando alternativas de tarefas, como vender roupa ou fazer bolo por encomenda, ou conseguem trabalhar em campos considerados femininos pela sociedade - 0 emprego doméstico ou de cuidados

A independência, a sensibilidade e o afeto são características da mulher esperadas pela sociedade, influenciando seu papel na família e na maternidade. A maternidade, embora considerada opcional, ainda é considerada pelas entrevistadas como parte indissociável da identidade feminina (SANTOS; NOVELINO; NASCIMENTO, 2011). Ser mãe, para as entrevistadas da geração Baby Boomer, foi um caminho natural enaltecido por suas mães e por outros membros da família. Não ter filhos ou marido era considerado inaceitável por muitas. Ilda, por nunca ter se casado e nunca ter tido filhos, conta em sua entrevista que sofreu pressão da família e comentários jocosos relacionados à sua feminilidade e opção.

O discurso atual da exigência da maternidade é questionado por entrevistadas da geração Millennials. Juliana é a única que não tem filhos, não tem vontade de os ter e mesmo com os novos valores familiares de maior liberdade de costumes, escuta brincadeiras dos pais (Baby Boomers) que estão querendo netos. Paula, Flavia, Erica, Tatiana, Luísa, Leila e Ana saíram da casa dos pais ao se casarem e foram mães relativamente cedo, para o pensamento atual, quando mulheres estão tendo filhos cada vez mais tarde, preferindo ter mais tempo para firmarem em uma carreira.

Mesmo com o avanço e as conquistas das mulheres na busca de igualdade de direitos na sociedade, as entrevistadas Baby Boomers mostraram traços de que ainda continuam com comportamentos e crenças relacionados ao papel feminino obrigatório de ser mãe e dona de casa. Mas também reconhecem a complexidade do momento, como Maria diz: "hoje em dia, elas tão mostrando que são mais guerreiras, né? Conseguem trabalhar, dá conta de marido, dá 
conta de filho e dá conta do trabalho", ilustrando a sobrecarga sofrida pela mulher e seu papel central nessas tarefas.

As participantes da geração Millennials, diferentemente das Boomers, não reproduziram falas que contradizem o seu pensamento de independência e de liberdade para as mulheres atuais. O sonho do casamento de véu e grinalda ficou para trás. "Morar junto" é a nova expressão para casamento. Quatro das entrevistadas (Paula, Luísa, Flavia e Leila) consideram-se casadas, acrescentando que vivem uma relação de casal sem vínculo formal. Isso pode indicar que valores de constituição de família estão em processo de mudança e vêm sendo incorporados em suas vidas. O casamento e a maternidade também passam a ser vistos de outra forma, como Erica falou:

“Na verdade, a mulher, né. Na minha visão, na minha
concepção, no meu tipo de criação familiar, ela continua
é... compondo a família desassociada de um casamento,
de ter um marido, de ter filhos. Mas, essa mulher ela sai
né, pro mercado de trabalho pra correr atrás pra ajudar a
sustentar a família é... junto com o marido, tomando as
decisões importantes tanto na sociedade, tanto em casa.
Antes a mulher era posta à margem das decisões e o
homem tomava as decisões sozinho, mas, ela é chamada
agora pra essa discussão, ela é ouvida ou deveria ser,
porque a gente sabe que muitas realidades em alguns
lares não é assim" (Erica).

O papel social, construído culturalmente, e a dicotomia sexual homemmulher, apontados em Negreiros e Carneiro (2004), vieram à tona nas entrevistas. Para Paula, "o homem pode falar e fazer qualquer coisa, já a mulher não, tem que ser delicada, educada, feminina e mais sei lá o que. Ditam o que o homem e a mulher têm que ser".

\subsection{Marca}

Ao lembrarem da marca Disney, a primeira impressão e lembrança das entrevistadas da geração Baby Boomers foram os personagens, filmes e o encantamento proporcionado pela marca, com sua magia e sonhos. A 
associação foi através de elementos marcantes de contos de fadas: castelos, magia e personagens, princesas e príncipes. Tanto as entrevistadas Millennials, quanto as Boomers lembraram dos desenhos, castelos, filmes e princesas. No entanto, o sonho de conhecer os parques e a figura central da marca, o Mickey, foram enfatizados apenas pelo grupo Millennials.

Para as entrevistadas da geração Baby Boomers, o que chamou mais a atenção foi a figura do príncipe e do amor verdadeiro. A falta dos finais românticos com o casamento e com os "felizes para sempre" dos filmes atuais foi sentida. Carla e Amanda expressaram a necessidade de salvação pelo homem do fardo de vida que viviam, através da realização do casamento. $O$ casamento, para elas, é a solução, até porque suas famílias jamais deixariam que saíssem de casa sem que fosse para casar e morar com o marido.

"Uma vez eu falei assim, eu ainda vou ser que nem uma Cinderela, eu tenho fé em Deus que um dia eu vou conseguir um príncipe e foi o que aconteceu, aconteceu de eu ter conhecido o meu marido e foi como ele caiu como se fosse um príncipe pra mim, porque ele me tirou daquela vida sofrida, de tantos problemas, de tantos trabalhos e me deu uma vida de Cinderela, entendeu?" (Amanda).

Ficou evidente nesta fala que o antigo papel da mulher está em ser alguém para agradar o futuro marido, o provedor do sustento. Assim como apontado por Rozario (2004) e Silverman (2009), as participantes entenderam que as princesas clássicas eram a personificação desse papel da mulher tradicional, que sonha com o príncipe encantado. O novo papel da mulher, da independência e da liberdade de escolha, é representado pelas novas princesas.

O alinhamento da marca com a realidade da sociedade e o papel feminino atual retratado foi visto como essencial para se enquadrar às mudanças socioculturais. Quinze entrevistadas consideraram a mudança do papel feminino retratado pela marca como algo necessário e positivo. Apenas uma entrevistada, da geração Millennials (Flavia), considerou a mudança como negativa. Para ela, os novos filmes estão mais artificiais, com pouca emoção, e menos reais do que os antigos. Flavia sente falta da presença do príncipe e do final "felizes para sempre" com o casamento, o que se assemelha com os pensamentos de Amanda, Maria e Irene da geração Baby Boomers 
As que consideraram a mudança positiva (Iza, Augusta, Gabriela, Carla, Ilda, Juliana, Paula, Erica, Tatiana, Luísa, Leila e Ana) gostaram dos novos finais, "mais reais", por mostrarem que a mulher pode ser feliz sozinha e se completar com outros tipos de amor, pela irmã ou pelos filhos. Por coincidência ou não, as que se divorciaram, ou são solteiras, aceitaram melhor esses novos finais, por acreditarem ser importante mostrar que a mulher pode ser feliz sozinha.

É interessante mostrar que, assim como Lancaster e Stillman (2002) e Zemke et al. (2000) salientaram, as entrevistadas Baby Boomers mostraram-se abertas às mudanças e à libertação das mulheres. A mudança das características femininas fez com que as novas princesas fossem comparadas com o novo papel da mulher atual e as antigas com o anterior. Essa transformação foi encarada pelas entrevistadas como positiva e necessária para a marca, mesmo que não seja vivida dentro da própria casa.

\begin{abstract}
"Mudou... mudou um pouco, sim. No antigo era aquela menina recatada, fazia tudo para o príncipe, para o pai dela, príncipe não, o rei mandava fazer. A espera do... era prometida no caso. E hoje não... hoje a princesa é totalmente diferente. Uma princesa, hoje, ela escolhe o marido que ela quer, o príncipe que ela quer no caso, se tiver o príncipe, se não tiver... também, não precisa. Hoje em dia acho que não precisa de maneira nenhuma do homem" (Gabriela).
\end{abstract}

"Eu entendo que a mulher é livre para ser o que quiser, para fazer o que quiser, sem depender de ninguém. Porque muito antigamente era isso, a mulher tinha que ficar em casa, fazer as coisas enquanto o homem trabalha. Como tudo mudou, eu acho que a mulher tem que ser livre para ela ser o que ela quiser, ficar com quem ela quiser, vestir o que ela quiser e é isso" (Leila).

Para Howe e Strauss (2000), os Millennials, por assumirem o arquétipo de heróis, são mais tradicionais e conservadores do que as gerações anteriores. Isso não foi identificado de forma tão clara nas falas. Pelo contrário, as 
participantes mostraram-se resilientes a valores do passado, mas atentas e abertas às mudanças, ao perceberem a evolução do papel da mulher na sociedade. Por coexistirem bem com as diferenças, aceitarem as diversidades e respeitá-las, aproximaram-se das descrições dos estudos de Loiola (2009), Raines (2000), Zemke et al. (2000), Twenge (2006) e Gronbach (2008).

\subsection{Personagens}

Das oito entrevistadas Baby Boomers, quatro (Amanda, Augusta, Maria e Carla) demonstraram identificação com as antigas princesas, em especial Cinderela, por trabalharem desde muito jovens e, muitas vezes, forçadas, para sobreviver, até mesmo pela madrasta. Duas delas, Carla e Amanda, relataram que, na infância, foram muito maltratadas pela madrasta e obrigadas a trabalhar para ela e para as irmãs. Na geração Millennials, novas princesas foram mencionadas. Ana, Paula, Juliana, Leila e Tatiana identificaram-se com as princesas contemporâneas ou com as princesas rebeldes, em especial Mulan. A princesa mais mencionada pela antiga geração, Cinderela, representa filme marcante e lembrado, porém apenas uma entrevistada (Flavia) identificou-se com a personagem.

\footnotetext{
"Eu quando era criança né, passei muita dificuldade, entendeu? Ela me botava para fazer as coisas e as filhas dela, e a filha dela, que não era nem minha irmã, era só filha dela. Ficava vendo televisão, vendo desenho que... que gostava e eu tinha que ficar lavando louça, varrendo chão, que eu tinha mais ou menos 12 anos por aí, assim, né. E... e a filha dela nada fazia e eu que tinha que lavar banheiro, lavar louça, cuidar de tudo, entendeu?" (Carla).
}

O filme Frozen (2014) também foi mencionado por todas as entrevistadas, tanto Boomers quanto Millennials, considerado por elas o primeiro a mostrar o amor verdadeiro como possível entre irmãs e por não ser necessário um príncipe salvar a princesa indefesa. As participantes da geração Baby Boomers ressaltaram a importância da família e no quanto é importante amá-la e ajudá-la diante das dificuldades. As Millennials frisaram o poder de escolha da mulher de 
querer casar-se ou não, já que o filme, diferentemente dos antigos, não termina em casamento.

\begin{abstract}
"Eu acho que eles são essenciais para mostrar que a gente não precisa é... de um casamento de um final com príncipe para ser feliz. Porque, quando demonstra isso, quando passa isso no filme de princesa é... principalmente para crianças, passa a ideia de que você só vai ter um final feliz se você tiver um casamento com uma pessoa maravilhosa e aquele vai ser o seu final feliz. Então, eu acho que é extremamente necessário também mostrar que, você pode ser feliz se você não casar, se você não tiver um príncipe, se você não encontrar um grande amor (Juliana).
\end{abstract}

Um ponto muito importante levantado pelas Millennials foi a relação entre a aparência física e a identificação. Tiana, a única princesa negra da Disney, foi escolhida por Tatiana, pelas características físicas e determinação para conseguir as coisas que quer. Outra participante, Erica, não se identifica por completo com nenhuma princesa Disney por não ter o corpo padrão e não se achar feminina como elas. Chega a mencionar uma princesa de outra marca, a Fiona, do filme Shrek. Porém, fica feliz com as mudanças já feitas pela Disney ao colocar princesas negras e de outras culturas, como Moana, e mais guerreiras, como Valente.

A aparência física das personagens não chamou muito a atenção das entrevistadas Boomers. Iza e Augusta comentaram sobre as vestimentas, sobre os vestidos que eram parecidos com os da época delas. Entretanto, a história teve muito mais importância na identificação do que os atributos físicos, pois, mesmo não sendo fisicamente parecidas com algumas princesas, elas se identificavam por conta do enredo.

Outro aspecto importante foi a mudança de valores das entrevistadas devido à evolução e à ressignificação do papel da mulher, que influenciou na identificação com as novas princesas quando atingiram a maturidade. Esse pensamento pode ser ilustrado nos trechos da entrevista de Ana: 


\begin{abstract}
"Antigamente eu... pensava muito, gostava muito, pensava muito de ser como essas princesas né, sonhava muito ah... o príncipe encantado e não sei o que, a gente tinha essa fantasia. Hoje em dia não! Antigamente eu pensava em ser, assim, como é... ter essa... essa possibilidade, né. Mas, hoje em dia eu vejo que é totalmente diferente é como... é a realidade né, porque a gente tem que correr atrás dos nossos objetivos tudo, a gente não tem que depender, esperar que alguém faça por nós, entendeu? A gente tem que correr atrás e... e procurar a nossa felicidade com o nosso esforço, não procurar através de uma outra pessoa. E é isso que os filmes de hoje da Disney mostram que, assim, nós somos capazes de buscar nossa felicidade também, entendeu? Não dependendo do próximo" (Ana).
\end{abstract}

Acompanhando a evolução dos papéis, as entrevistadas ressaltaram que o termo princesa ganhou um novo significado. Princesa, antes, era uma menina recatada, arrumada e que obedecia ao marido. Hoje, ser princesa é ter o poder de escolha, ter o livre arbítrio da própria vida. Para elas, o termo princesa foi criado pela Disney e está sendo descontruído pela marca quando passa a mostrar guerreiras mais próximas de super-heroínas.

A mudança de valores que ocorre na sociedade faz com que as entrevistadas busquem por mais representatividade $e$ diversidade nas personagens. Ser princesa e recatada não é visto como uma boa escolha para os dias de hoje. Há o desejo de histórias com princesas mais reais, que trabalham, estudam, criam os filhos sozinhas e, acima de tudo, tem liberdade de escolha, do que ser e fazer, independente da vontade do homem ou da sociedade. 


\section{Considerações finais}

Este estudo teve como propósito identificar como o papel de personagens femininas da marca Disney é interpretado, a partir de valores, crenças e comportamentos, por mulheres de baixa renda representantes das gerações Baby Boomer e Millennial, e como influencia na sua percepção da marca Disney.

Autores já estudaram temas que indicam a coexistência do papel feminino tradicional com o atual, baseados na visão de mundo, valores, representações sociais e família. Entretanto, ao estudarem identificação, utilizaram celebridades ou personagens reais. Este estudo descola-se da figura de personagens reais, focalizando naquelas criadas em filmes infantis, comparando valores de diferentes culturas representadas por diferentes coortes.

Apoiando-se nas teorias dos papéis sociais femininos e masculinos, de Parsons (1970) e de Negreiros e Carneiros (2004); de Mannheim (1993), Motta, Rossi e Schewe (1999, 2002), Howe e Strauss (2000) sobre gerações; de Biasoli-Alves (2000), Bruschini (2008), Saffioti, (2001) em relação ao papel feminino dentro de cada geração; Côrte-Real e Lencastre (2012) e McCracken (2005) acerca de marca e personagens; e de Randazzo (1996), Rozario (2004), Silverman (2009) para entender os tipos de princesas Disney, a investigação buscou alicerçar teoricamente o estudo aqui desenvolvido.

Os achados mostram traços relacionados ao pensamento de Duarte (2008), que diz ser possível a mudança na relação entre família e gênero nas camadas populares, uma vez que as entrevistadas apontaram novas configurações familiares, nas quais o homem não era o único provedor de sustento da família e o casamento não era essencial. Esses traços entram em conflito com Heilborn (1995) e Rocha-Coutinho (2006), que consideram a forte presença do tradicionalismo nas relações familiares em classes populares, onde o homem é o único provedor do sustento e atuante na esfera pública.

Ademais, a rede de associação de Schmitt e Simonson (2002) onde a marca ocupa metaforicamente uma espécie de arquivo na mente do consumidor, acessado quando ela é ativada, surgiu nas entrevistas. Entretanto, cada participante, por ter vivenciado diferentes experiências, absorveu, armazenou e percebeu a marca de forma distinta. Por participar dos mesmos eventos marcantes e ter os mesmos valores geracionais, seu coorte influenciou na identificação e na preferência pela marca, o que ocasionou reações e percepções semelhantes em algumas. No entanto, é a história de vida que 
prevalece na hora da escolha da personagem com que mais se sente representada.

A vida passada e presente influencia em como a marca Disney é vista por elas. A identificação com as personagens se dá muito mais por proximidade em relação à sua história no filme do que por aspectos físicos, sugerindo que conhecer os seus momentos de vida foi crucial para entender escolhas e preferências. As princesas da Disney, mesmo tendo sido adaptadas de outras histórias assemelham-se a mascotes, por serem personagens criadas com forma humana e traços selecionados e estarem vinculadas apenas a uma marca, a Disney. São celebridade ao se tornarem reconhecidas na mídia em favor de um bem de consumo - filmes e produtos relacionados.

Ao entrar em contato com o produto, um significado é gerado levando em consideração memórias afetivas, valores e crenças. Após o consumo, sentimentos que as personagens e enredo geram são organizados e interpretados de forma positiva ou negativa em relação a marca. Valores pessoais influenciam na decisão de consumo e precisam estar alinhados com valores organizacionais transmitidos pela marca, visto que as consumidoras que tiveram uma reação positiva às mudanças das personagens, as consideraram necessárias por exprimir seus próprios valores.

No grupo de mulheres da geração Baby Boomer, a princesa mais mencionada e escolhida foi Cinderela, considerada a representação da mulher dos anos 1950 (KRAUSE, 2014). No grupo da geração Millennial, três princesas tiveram destaque: Anna e Elsa, do filme Frozen e Moana. Elas foram retratadas como exemplos do papel da mulher atual, guerreira, que vai em busca do que quer, sem depender de homem para salvá-la.

Evidenciou-se que discussões sobre gênero e independência da mulher ganharam mais força na mídia, fazendo com que os consumidores passem a contestar mais posicionamentos da marca. Embora a marca Disney tenha expandido a diversidade física e cultural de suas personagens, explorando o que seria a "terceira mulher" de Lipovetsky (2000), com novos enredos e princesas mais independentes e com opção de escolha em relação ao casamento, para as participantes deste estudo a mudança ainda não foi suficiente, faltando particularidades a serem exploradas. No aspecto físico, princesas fora do "padrão de beleza" são esperadas; no enredo, histórias mais reais, com princesas que estudam, trabalham e são mães são aguardadas.

Além do reconhecimento dado à marca por alinhar-se com a evolução da sociedade, as entrevistadas mostraram forte relação afetiva com os filmes e 
personagens, pois a marca mostrou-se presente em vários momentos de suas vidas, tanto na infância quanto na fase adulta. Atualmente, sua forma de atingir o público adulto na tentativa de resgatar momentos nostálgicos está sendo feita através dos live-actions, que contam com a mesma trama, porém com algumas modificações para se enquadrarem aos novos pensamentos da sociedade. Além disso, as entrevistadas que são mães ou avós e as que ainda não o são e querem ser, deixaram claro que incentivarão suas (seus) filhas (os) ou netas (os) a consumirem novos filmes e produtos da Disney.

Essas revelações mostram-se interessantes para as organizações que exploram segmentos geracionais como público, para ofertarem produtos e criarem personagens que acompanhem as mudanças da sociedade e estejam de acordo com os valores e comportamentos desses grupos geracionais.

A conquista das mulheres e a luta pela igualdade de direitos mostra-se muito presente e discutida na sociedade atual. Por isso, o tema merece ser estudado e entendido em todas as áreas, mais especialmente na área de Marketing, uma vez que as mulheres são consumidoras assíduas de vários produtos e mostram capacidade de relacionar, de forma reflexiva, aspectos da vida cotidiana com o que lhes é oferecido.

Sugere-se que, a partir deste estudo, sejam desenvolvidos trabalhos que ampliem o perfil de entrevistados para outras gerações e classes sociais, para maior abrangência de representantes e ampliação das descobertas. Também seria interessante comparar opiniões masculinas acerca da evolução do papel feminino na sociedade e a criação de personagens que as retratem. 


\section{Referências Bibliográficas}

AMA - American Marketing Association. Marketing Definitions: A Glossary of Marketing Terms, Chicago 1960.

ARAÚJO, C.; SCALON, C. Percepções e atitudes de mulheres e homens sobre conciliação entre família e trabalho pago no Brasil. In C. Araújo \& C. Scalon (Orgs.). Gênero, trabalho e familia no Brasil. Rio de Janeiro: FGV, 2005, p. 15-88.

De BEAUVOIR, S. O Segundo Sexo: a experiência vivida. 2. ed. São Paulo: Difusão Européia do Livro, 1967.

BETTELHEIM, B. A psicanálise dos contos de fadas. 29. ed. Rio de Janeiro/são Paulo: Paz e Terra,. 2014.

BIASOLI-ALVES, Z. M. M. Continuidades e rupturas no papel da mulher brasileira no século XX. Psicologia: Teoria e Pesquisa, 16(3), 2000, p. 233-239.

BREDER, F.C. Feminismo e príncipes encantados: a representação feminina nos filmes de princesa da Disney. Monografia (Graduação em Comunicação Social/ Jornalismo) - Universidade Federal do Rio de Janeiro - UFRJ, Escola de Comunicação - ECO. Rio de Janeiro, 2013.

BRUSCHINI, M.C.A.; RICOLDI, A.M. Articulação trabalho e família: famílias urbanas de baixa renda e políticas de apoio às trabalhadoras. São Paulo: FCC/DPE, 2008.

CASTILHOS, R.; ROSSI, C. A. Subindo o morro: consumo, posição social e distinção entre famílias de classes populares. In: ROCHA, A.; SILVA, J. (orgs.) Consumo na Base da Pirâmide - estudos brasileiros. Rio de Janeiro: Mauad X, 2009.

CINDERELA (Cinderella). Direção: Clyde Geronimi, Hamilton Luske e Wilfred Jackson. Produção: Walt Disney. Walt Disney Productions, 74 min, cor. 1950.

CÔRTE-REAL, A; de LENCASTRE, P. As crianças e as marcas: que relação possível? Um olhar a partir das mascotes. Signos do consumoV.4, N.1, P. 57-65, 2012.

DIAS, A.M; CASSIANO, C. M. A imagem da mulher na propaganda da Avon. 2010.

DOWLING, C. Complexo de Cinderela. São Paulo: Melhoramentos, 1981.

DRAEGER, J. Do Fogo do Inferno ao Frio Congelante, Frozen e as Representações das Mulheres. Monografia (Monografia na Faculdade de Comunicação - Publicidade) Faculdade de Comunicação, Universidade de Brasília, Brasília, 81 f, 2015.

DUARTE, L.F.D. GOMES, E.C. Três Famílias Identidades e Trajetórias Transgeracionais nas Classes Populares, Editora FGV, Rio de Janeiro, 2008.

ENGLAND, D.E; DESCARTES, L; COLLIER-MEEK, M.A. Gender Role Portrayal and the Disney Princesses. 64:555-567. Sex Roles, 2011. 
FERREIRA, J.D S. Merida e Elsa: as princesas do século XXI. Monografia (Graduação em Comunicação Social/ Jornalismo) - Universidade Federal do Rio de Janeiro - UFRJ, Escola de Comunicação - ECO. Rio de Janeiro, 2015.

FIGUEIRA, S.A. Modernização da Família e Desorientação; Uma das Raízes do Psicologismo no Brasil. In: Figueira, S. A. (org.). Cultura da Psicanálise. São Paulo: Brasiliense,142-147, 1981.

(org.) Uma Nova Família? O moderno e o arcaico na família de classe média brasileira. Rio de Janeiro: Zahar, 1987.

Nos Bastidores da Psicanálise. Rio de Janeiro: Imago, 1991.

FROZEN. Direção: Chris Buck, Jennifer Michelle Lee. Produção: John Lasseter e Peter Del Vecho. Walt Disney Pictures,108 min, cor, 2013.

FANTÁSTICO. Princesas mais famosas do cinema fazem participação juntas em novo filme da Disney. Dezembro de 2018. Disponível em: $<$ https://g1.globo.com/fantastico/noticia/2018/12/23/princesas-maisfamosas-do-cinema-fazem-participacao-juntas-em-novo-filme-dadisney.ghtml . Acessado em 20 de março de 2019.

GIROUX, H. A dysneização da cultura infantil. In: SILVA, Tomaz Tadeu da; MOREIRA, Antônio Flávio (orgs.) Territórios contestados: o currículo e os novos mapas políticos e culturais. Petrópolis: Vozes, p, 41-81, 1995.

GROENEWALD, T.A phenomenological research design illustrated. International Journal of Qualitative Methods, 3 (1), 2004.

GRONBACH, K. W.; The Age Curve, How to Profit from the Coming Demographic Storm. New York, American Management Association, 2008.

GROSSI, P.; MOTTA, P. C. M.; HOR-MEYLL, L. F. O Risco Percebido na Compra de Alimentos por Consumidores de Baixa Renda. In: encontro de marketing da anpad, 3., 2008, Curitiba. Anais, Rio de Janeiro: ANPAD, 2008.

GUNDELACH, P. Panorama des changements valeurs recentes em Europe Occidentale. A New Europe de Base, 2, 3-27, 1991.

HEILBORN, M.L. "O que faz um casal, casal? Conjugalidade, Igualitarismo e identidade Sexual em Camadas Médias Urbanas". In: Famílias, Processos Contemporâneos: Inovações Culturais na Sociedade Brasileira, Edições Loyola, São Paulo,1995.

HOWE, N; STRAUSS, W; Millennials Rising - The Next Great Generation. Vintage Books - Random House Inc., New York, NY, 2000.

KELLER, K. L; MACHADO, M. Gestão estratégica de marcas. São Paulo: Pearson, 2006.

KRAUSE, Roberta Fleck Saibro. Audiovisualidades do papel feminino nos anos 1950 sob o olhar da publicidade televisiva. ComuniCon, São Paulo, Universidade do Vale do Rio dos Sinos, p.1-14, 2014.

LANCASTER, L. C.; STILLMAN, D.; When Generations Collide, HarperColins Publishers Inc., New York, NW. 2002. 
LIPOVETSKY, G. A terceira Mulher. Permanência e revolução do feminino. Maria Lucia Machado (trad.), São Paulo: Companhia das Letras, 2000.

O império do efêmero: a moda e seu destino nas sociedades modernas. São Paulo: Companhia das Letras, 1989.

LOIOLA, R. Geração Y. Revista Galileu. São Paulo, no 219, p. 50-53, out. 2009.

MADALOZZO, R., MARTINS, S., SHIRATORI, L. Participação no mercado de trabalho e no mercado doméstico: homens e mulheres têm condições iguais? Estudos Feministas, 18(2), 547- 566, 2010.

MAGALHÃES, A. S. Individualismo e conjugalidade: um estudo sobre $o$ casamento contemporâneo. Dissertação (Mestrado em Psicologia), Departamento de Psicologia, PUC-Rio, Rio de Janeiro, 132 pp, 1993.

MANNHEIM, K. "El problema de las generaciones" [tradução: Ignacio Sánchez de la Yncera], Revista Española de Investigaciones Sociológicas (REIS), n. 62, 1993.

MARTINS, E. S. Os Papéis Sociais na Formação do Cenário Social e da Identidade. Kínesis, Vol. II, n 04, p. 40-52, dezembro-47, 2010.

MCCRACKEN, G. Culture and consumption II: markets, meaning, and brand management. Bloomington: Indiana University, 2005.

MEREDITH, G., SCHEWE, C D., KARLOVICH, J.; Defining markets, defining moments: America's 7 generational cohorts, their shares experiences and why business should care. New York: Hungry Minds, Inc. 2002.

MOTTA, P.C., ROSSI, M.Z.G., SCHEWE, C.D. Generational Marketing: Exploring Cohort-Programmed Values and Their Implications on Crosscultural Variations in Consumer Behavior between Brazil and United States. Revista Portuguesa de Marketing, IPAM. Porto, 11-21, 2002.

Using Brazilian Cohort Values to Target TV Shoppers. Proceedings, "Conference on Telecommunications and Information Markets" - Cotim 99, 1999.

NEGREIROS, T. C. G. M.; CARNEIRO, T. F. Masculino e feminino na família contemporânea. Estudos e pesquisas em psicologia, v. 4, n. 1, p.34-47, 2004.

NOLASCO, S. O Mito da Masculinidade. Rio de Janeiro: Rocco, 1993.

A Desconstrução do Masculino. Rio de Janeiro, Rocco, 1995.

O FUXICO.COM. Entenda as mudanças do live-action de Mulan. Julho de 2019. Disponível em: https://www.ofuxico.com.br/noticias-sobrefamosos/entenda-as-mudancas-do-live-action-de-mulan/2019/07/14-

353607.html . Acessado em 15 de julho de 2019.

O GLOBO ONLINE. O que há de feminismo nas novas princesas Disney e nas releituras em live action como 'Aladdin'. Junho de 2019. Disponível em:

https://www.google.com.br/search?q=0+que+ha+de+feminismo+nas+nova 
$\mathrm{s}+$ princesas+o+globo+online+alice+cravo\&ie=\&oe=. Acessado em 16 de junho de 2019.

PARSONS, T. The Social System. London: Routledge \& Kegan Paul Ltd, 1970.

PARENTE, J. G. O varejo de alimentos para consumidores de baixa renda no Brasil. Relatório16/2008. FGV-EAESP/GVPesquisa, 2008.

PEREIRA, M. E. Psicologia social dos estereótipos. São Paulo: E.P.U., 2002.

PIRES, S. M. F. Amor romântico na literatura infantil: uma questão de gênero. Educar, Curitiba, n. 35, p. 81-94, 2009.

POESCHL, G. Trabalho doméstico e poder familiar: práticas, normas e ideais. Análise Social, XXXV (156), 695-719, 2000.

RAINES, C. Beyond Generation X: A pratical guide for managers. Course Tecnology: 2000.

RANDAZZO, S. A criação e mitos na publicidade: como os publicitários usam o poder do mito e do simbolismo para criar marcas de sucesso. Rio de Janeiro: Rocco, 1996.

ROCHA-COUTINHO, M. L. O papel de homens e mulheres na família: podemos falar em reestruturação? Psicologia Clínica, 15(2), 93-107, 2003.

Novas opções, antigos dilemas: mulher, família, carreira e relacionamento no Brasil. Temas em Psicologia, 12(1), 2-17, 2004.

Transmissão geracional e família na contemporaneidade. In: LINS DE BARROS, M. (Org) Família e Gerações, Editora FGV, Rio de Janeiro, 2006.

ROMANELI, G. O Relacionamento Pais e Filhos em Famílias de Camadas Medias. Paidéia, FFCLP_RP, Rib. Preto, Fev/Ago, p.123-136, 1998.

ROZARIO, R.A. C. The Princess and the Magic Kingdom: Beyond Nostalgia, the Function of the Disney princess. Women's Studies in Communication, Research Library pg. 34, 2004.

SAFFIOTI, H.I.B. Contribuições feministas para o estudo da violência de gênero. Cad. Pagu no. 16 Campinas. Disponível em: <http://www.scielo.br/scielo>, 2001.

SANTOS, M. F. S.; NOVELINO, A. M.; NASCIMENTO, A. P. O Mito da Maternidade: discurso tradicional sob roupagem modernizante? In: Moreira, A. S. P. (org.) Representações Sociais. Teorias e Práticas. EDU. João Pessoa, p.269-293, 2001.

SCHUMAN, H.; SCOTT, J.; Generations And Collective Memories; American Sociological Review, v.54, p.259-381, 1989.

SEGER, L. Como criar personagens inesquecíveis. São Paulo. Bossa nova, 236p, 2006.

SCHMITT, B; SIMONSON, A. A estética do marketing: como criar e administrar sua imagem e identidade. São Paulo: Nobel, 2002. 
SILVERMAN, R.A. New Dreams, Old Endings: Searching for "A Whole New World" in Disney Second-Wave Animated Romance Films. Faculty of Wesleyan University. Departmental Honors in Sociology, 2009.

TAPSCOTT, D. A Hora da Geração Digital: Como os Jovens Que Cresceram Usando a Internet Estão Mudando Tudo, das Empresas aos Governos. Rio de Janeiro: Agir Negócios, 2010.

THOMPSON, C.J; LOCANDER, W; POLLIO, H. Putting Consumer Experience Back into Consumer Research: The Philosophy and Method of Existential-Phenomenology. Journal of consumer research * vol. 16 * september, 1989.

TRINDADE, Z. A.; ANDRADE, C. A.; de SOUZA, J. Q. Papéis parentais e Representações da paternidade: A Perspectiva do Pai. Psico. Porto Alegre.V.28 n. 1, jan/jun, p. 207-222, 1997.

TWENGE, J. M.; Generation Me: why today's young Americans are more confident, assertive, entitled - and more miserable than ever before, Simon e Schuster, Inc., Free Press, 2006.

VAITSMAN, J. Flexíveis e plurais: identidade, casamento e família em circunstâncias pós-modernas. Rio de Janeiro: Rocco, 1994.

WARNER, M. Da Fera à Loira: sobre contos de fadas e seus narradores. São Paulo: Companhia das Letras, 1999.

ZEMKE, R.; RAINES, C.; FILIPCZAK, B. Choque de Gerações. Disponível em: <http://www.scribd.com/doc/15899660/Choque-de-Geracoes>, 2000.

ZIKMUND, W.G. Princípios da pesquisa de marketing. São Paulo: Pioneira Thomson Learning, 2006. 